\title{
PEMBANGUNAN EKONOMI MASYARAKAT MELALUI AGROWISATA
}

\author{
Abdurrahman Kader ${ }^{1}$, Darwin Abd. Radjak ${ }^{2}$ \\ ${ }^{1}$ Fakultas Ilmu Sosial dan Ilmu Politik, Universitas Muhammadiyah Maluku Utara \\ Korespondensi email: rahmankader78@gmail.com \\ ${ }^{2}$ Fakultas Ilmu Sosial dan Ilmu Politik, Universitas Muhammadiyah Maluku Utara \\ email: radjak_bila20@yahoo.co.id
}

\begin{abstract}
This study is aims to examine the economic development of the Kalaodi community through agrotourism. In particular, this study is aims to examine the development of the agricultural potential of the Kalaodi village as an agro tourist attraction in Tidore City, and home industry development as an effort to improve the community's economy. This research use the desciptive qualitative approach, and the data analysis technique used is an interactive model, with stages: data condensation, display data, drawing/verifiying. The results showed that the government of Tidore City did not yet have a Kalaodi agrotourism development program. However, the Kalaodi people have developed agriculture as an object of agrotourism. The business carried out by the community is utilizing the house yard as a family garden. In addition, the Kalaodi community has local wisdom in carrying out their profession as a farmer, namely farming that does not damage the forest and nature. This wisdom enriched the Kalaodi village agro tourism. The Kalaodi community also developed a home industry as a form of developing agrotourism in their village. Products of produced from the home industry are malinjo crackers and chips, souvenirs and jewelry and household furniture. Economically, the home industry business developed by the community has an impact on society such as helping the family economy.
\end{abstract}

Keyword: economic development; kalaodi agrotourism.

\begin{abstract}
ABSTRAK
Studi ini bertujuan untuk mengkaji tentang upaya pengembangan Ekonomi masyarakat Kalaodi melalui agrowisata. Secara khusus, studi ini bertujuan untuk mengkaji tentang pengembangan potensi pertanian kampung Kalaodi sebagai objek wisata agro Kota Tidore Kepulauan, dan pengembangan industri rumahan (home idustry) sebagai upaya peningkatan ekonomi masyarakat. Penelitian ini menggunakan pendekatan deskriptif kualitatif, dan teknik analisis data yang digunakan adalah model interaktif, dengan tahapan: kondensasi kata (data condensation), penyajian data (display data), dan kesimpulan/verivikasi (drawing/verifiying). Hasil penelitian menunjukan bahwa pemerintah Kota Tidore Kepulauan belum mempunyai program pengembangan agrowisata Kalaodi. Namun demikian, masyarakat Kalaodi telah mengembangkan pertanian sebagai objek agrowisata. Usaha yang dilakukan oleh masyarakat adalah memanfaatkan pekarangan rumah sebagai kebun keluarga. Selain itu, masyarakat Kalaodi memiliki kearifan lokal dalam menjalankan profesinya sebagai petani, yaitu bertani yang tidak merusak hutan dan alam. Kearifan tersebut memperkaya wisata agro kampung Kalaodi. Masyarakat Kalaodi juga mengembangkan industri rumahan sebagai bentuk pengembangan agrowisata di kampungnya. Produk yang dihasilkan dari industri rumahan tersebut adalah krepek dan emping malinjo, sovenir serta perhiasan dan perabot rumah tangga. Secara ekonomi, usaha home industry yang dikembangkan oleh masyarakat tersebut mempunyai dampak terhadap masyarakat seperti membantu ekonomi keluarga.
\end{abstract}

Kata Kunci: pengembangan ekonomi; agrowosata kalaodi. 


\section{PENDAHULUAN}

Pembangunan berkelanjutan secara konseptual dipahami sebagai suatu proses yang terdiri atas dimensi ekonomi, sosial-budaya dan lingkungan-ekologi. Konsep tersebut mencakup seluruh pembangunan kewilayahan, yaitu pembangunan nasional maupun pembangunan daerah, ataupun pembangunan perkotaan dan pedesaan. Maknanya adalah secara konseptual pembangunan berkelanjutana mengisyarakatkan bahwa dalam proses pelaksanaan pembangunan harus memberikan nilai manfaat secara ekonomi, sosialbudaya dan lingkungan-ekologi terhadap suatu wilayah atau kawasan pembangunan (Rosana, 2018).

Dalam konteks pembangunan pedesaan, program pembangunan masyarakat pedesaan dan pertaninan yang telah dijalankan oleh pemerintah telah mendatangkan hasil yang gemilang dan dapat dinimati oleh masyarakat. Namun demikin kita tidak bisa mempunkiri bahwa program ini memperoleh banyak kritik. Diantaranya adalah strategi pembangunan pertanian tidak secara optimal atau gagal menciptakan masyarakat desa lepas dari kemiskinan. Kegagalan itu terjadi bukan karena kebijakan itu keliru tetapi karena kurang disertai dengan upaya reformasi diseluruh sector (Yunas, 2018), termasuk sektor pertanian dan daerah pedesaan. Dalam kontek pembangunan pertanian Indonesia, (Rivai \& Anugrah, 2011) menyebutkan masih banyaknya ditemukan masalah-masalah yang berkaitan dengan kerusakan lingkungan dan degradasi sumber daya alam.

Selian dinamika di atas, pada sisi yang lain, pemerintah melalui program pembangunan infrastrukturnya seperti jalan tol dan kawasan industri, serta proyek konversi dan alih pertanian yang dilakukan oleh perusahan, baik BUMN maupun swasta. Proyek-proyek tersebut masuk ke daerah pedesaan yang menggunakan lahan yang tidak kecil. Pembangunan infrastruktur masuk desa tersebut yang kemudian menyebakan penyempitan lahan pertanian di daerah pedesaan. dari salah satu penyebab semua itu adalah adanya ego sektoral yang selalu ditonjolkan oleh masing-masing unit pelaksana pembangunan yang menyebabkan dalam proses pelaksanaannya menjadi tersekat dan parsial (Rivai \& Anugrah, 2011).

Ketika merefleksi ke belakang, pada masa pemerintahan Orde Baru, pertanian benar-benar menjadi pengerak perekonomian masyarakat. Pemerintah Orde Baru memfasilitasi masyarakat pendesan dengan berbagai bentuk kebijakan seperti listrik masuk desa, koran masuk desa, sekolah Inpres dan lainnya (Permana, 2010). Pemerintahan Orde Baru berhasil membangun sektor pertanian pedesaan, dan menjadikan pertanian sebagai sektor penting dalam kebijakan pembangunan nasionalnya. Kebijakan tersebut membuahkan hasil, dimana sektor pertanian dapat menyerap tenaga kerja dan memberi pendapatan bagi sebagian besar rumah tangga masyarakat pedesaan di Indonesia.

Secara konseptual, pembangunan pertanian di daerah pedesaan mempunyai peran sangat besar terhadap pengembangan lingkungan dan perekonomian masyarakat. Diantara manfaat pertanian bagi keberlangsungan lingkungan dan kehidupan manusia adalah sebagai penyedia oksigen, pertanian sebagai penyedia air, pertanian sebagai penyedia pangan, pertanian sebagai penyedia faktor keamanan, pertanian sebagai sumber nafkah (bidang pekerjaan), pertanian sebagai faktor sosio-politik, pertanian sebagai penyedia bahan baku industri, dan pertanian sebagai industri pariwisata dan kesehatan rohani (Sudalmi, 2010).

Kampung Kalaodi merupakan sebuah kampung kecil yang berda di Kota Tidore Kepulauan. Kampung kecil tersebut yang telah diatur dalam kebijakan pariwisata daerah Kota Tidore Kepulauan (Perda Nomor 9 Tahun 2015 tentang RIPPARDA) sebagai objek agrowisata. Dengan kebijakan daerah tersebut maka pemerintah daerah dan masyarakat 
harus bersama-sama bahu-membahu untuk mengembangkan sektor pertanian kampung Kalaodi secara terencana dalam rangka untuk merealisasikan konsep pengembangan agrowisata Kalaodi sebagai objek wisata unggulan daerah sebagaiman dikonsepkan oleh pemerintah daerah dalam dokumen kebijakannya.

Dokumen kebijakan daerah tentang kepariwisataan, yaitu pada Pasal 20 Peraturan Daerah Nomor 9 Tahun 2015 tentang RIPPARDA, Pemerintah Kota Tidore Kepulauan menjadikan agrowisata Kalaodi sebagai objek wisata unggulan daerah. Dengan dokumen kebijakan daerah tersebut maka Pemerintah Kota Tidore Kepulauan mempunyai kewajiban untuk membangun sektor pertanian di kampung Kalaodi, yang nantinya sebagai objek wisata agro. Pemerintah harusnya memfasilitasi masyarakat Kalaodi untuk mengembangkan pertaniannya sehingga mempunyai daya tarik, sehingga para wisatawan tertarik untuk mengunjungi kampung Kalaodi sebagai objek wisata agro daerah.

\section{TINJAUAN PUSTAKA}

\section{Pariwisata}

Pariwisata secara konseptual, dari sisi defenisi operasional pengertian pariwisata, masih belum terdapat kesepakatan tetang pengertian pariwisata dari para sarjana ilmu pariwisata. Diksi pariwisata yang biasa digunakan oleh halayak umum di Indonesia merupakan kata sarapan yang berasal dari bahasa Sansekerta. Secara etimologi, kata pariwisata terdiri atas dua suku kata yaitu pari dan wisata. Pari berarti "banyak" atau "berkeliling", sedangkan wisata berarti "pergi" atau "bepergian". Merujuk pada kata darasar tersebut, maka pariwisata dapat diartikan sebagai perjalanan yang dilakukan berkali-kali, berputar-putar atau berkeliling, dari suatu tempat ke tempat lain. Dalam bahasa Inggris disebut dengan kata "tour", sedangkan untuk pengertian jamak, kata "Kepariwisataan" dapat digunakan kata "tourisme" atau "tourism" (Suwena \& Widyatmaja, 2017).

Undang-undang Nomor 10 Tahun 2009 tentang Kepariwisataan, menjelakana tentang konsep kepariwisataan sebagai berikut:

a. Wisata adalah kegiatan perjalanan yang dilakukan oleh seseorang atau sekelompok orang dengan mengunjungi tempat tertentu untuk tujuan rekreasi, pengembangan pribadi, atau mempelajari keunikan daya tarik wisata yang dikunjungi dalam jangka waktu sementara.

b. Pariwisata adalah berbagai macam kegiatan wisata dan didukung berbagai fasilitas serta layanan yang disediakan oleh masyarakat, pengusaha, Pemerintah, dan Pemerintah Daerah.

c. Kepariwisataan adalah keseluruhan kegiatan yang terkait dengan pariwisata dan bersifat multidimensi serta multidisiplin yang muncul sebagai wujud kebutuhan setiap orang dan negara serta interaksi antara wisatawan dan masyarakat setempat, sesama wisatawan, Pemerintah, Pemerintah Daerah, dan pengusaha

Suwena dan Widyatmaja (2017) menyebutkan bahwa dalam pengertian kepariwisataan terdapat beberapa faktor penting yaitu: 1). Perjalanan itu dilakukan untuk sementara waktu; 2). Perjalanan itu dilakukan dari suatu tempat ke tempat lain; 3). Perjalanan itu; walaupun apapun bentuknya, harus selalu dikaitkan dengan pertamasyaan atau rekreasi; dan 4). Orang yang melakukan perjalanan tersebut tidak mencari nafkah di tempat yang dikunjunginya dan semata-mata sebagai konsumen di tempat tersebut. Terkait dengan hal tersebut Yu, et. al., (2012) menjelaskan sebagai berikut: 
A visitor is a traveler taking a trip to a main destination outside his/her usual environment, for less than a year, for any main purpose (business, leisure or other personal purpose) other than to be employed by a resident entity in the country or place visited. These trips taken by visitors qualify as tourism trips. By applying the three criteria of the geographical dimension (outside usual environment), the temporal dimension (length of stay), and purpose of trip, tourism is delimited as a subset of travel and visitors as a subset of travelers.

Camilleri, (2018) menjelaskan bahwa "Individuals become tourists when they voluntarily leave their normal surroundings, where they reside, to visit another environment.... Therefore, tourists are visitors, and what they you do whilst visiting another place may be considered as tourism." Lebih lanjut Camilleri, (2018) mengutip United Nations Conference on International Travel and Tourism yang lebih sepakat untuk menggunakan istilah 'visitors' untuk menjelaskan tentang orang yang melakukan perjalanan mengunjungi negara lain (Camilleri, 2018).

\section{Agrowisata}

Secara umum agrowisata adalah aktifitas kepariwisataan yang berkaitan dengan sektor pertanian. Objek dari agrowisata yang dinikmati wisatawan adalah memanfaatkan usaha atau industri pertanian (agro). Secara konseptual Nurisjah menjelaskan bahwa agrowisata atau wisata pertanian dapat dimaknai sebagai rangkaian aktivitas perjalanan wisata yang memanfaatkan lokasi atau sektor pertanian mulai dari awal produksi hingga diperoleh produk pertanian dalam berbagai sistem dan skala dengan tujuan memperluas pengetahuan, pemahaman, pengalaman, dan rekreasi di bidang pertanian (Budiarti et al., 2013). (Rambodagedara et al., 2015) menjelaskan "agro-tourism has become an increasingly popular concept across the world as it provides a specific focus to diversify income generating activities for farmers, ultimately leading to rural development".

Pengertian agrowisata dalam Surat Keputusan Bersama Menteri Pertanian dan Menteri Pariwisata, Pos, dan Telekomunikasi Nomor: 204/KPTS/ HK/050/4/1989 dan Nomor KM. 47/PW.DOW/MPPT/89 Tentang Koordinasi Pengembangan Wisata Agro, didefinisikan "sebagai suatu bentuk kegiatan pariwisata yang memanfaatkan usaha agro sebagai obyek wisata dengan tujuan untuk memperluas pengetahuan, perjalanan, rekreasi dan hubungan usaha di bidang pertanian".

Merujuk pada pengertian tersebut dapat dijelaskan bahwa agrowisata merupakan bagian dari objek wisata yang memanfaatkan usaha pertaninan (agro) sebagai objek wisata. Tujuan dari kegiatan tersebut adalah untuk memperluas pengetahuan, pengalaman rekreasi, dan hubungan usaha pada bidang pertanian. Harapannya, dengan aktifitas agrowisata tersebut dapat meningkatkan pendapatan petani, melestarikan sumberdaya lahan, dan terjaganya keknologi pertanian lokal. Pengembangan agrowisata dapat memberikan dampak terhadap upaya pembangunan pertanian berkelanjutan dari sudut pandang ekologi, sosial, ekonomi dan pengelolaan (Pambudi et al., 2018).

Terkait dengan hal tersebut dapat dijelaskan bahwa agrowisata adalah sebuah sistem kegiatan yang terpadu dan terkoordinasi untuk mengembangkan pariwisata sekaligus pertanian, dalam kaitan dengan pelestarian lingkungan, dan peningkatan kesejahteraan masyarakat (Situmorang \& Suryawan, 2017). Selain itu, Departemen Pertanian menjelaskan bahwa agrowisata merupakan salah satu kegiatan yang bersifat bisnis pada bidang pertaninan dengan cara menjual jasa pelayanan kepada konsumen. 
Bentuk jasa yang dijual tersebut berupa keindahan alam, kenyamanan ketenraman, dan pendidikan (Syafira, 2017).

\section{Pariwisata Sebagai Media Pembangunan Ekonomi Masyarakat}

Merujuk pada pengertian pariwisata sebagaimana dijelaskan di depan maka dapat dimaknai bahwa pariwisata merupakan sebuah aktifitas yang melibatkan banyak pihak, lintas sektoral dan bahkan lintas negara. Dengan demikan maka, dalam prespektif ekonomi, pariwisata merupakan sebuah industri yang melibatkan banyak pelaku usaha, baik lokal, domestik dan internasional. Dengan demikian maka dalam perkembangan terakhir, pariwisata telah menjadi salah satu sektor pembangunan ekonomi yang sedang digalakkan dan diperkuat oleh pemerintah, baik pemerintah pusat maupun daerah.

Terkait dengan hal tersebut, merujuk pada berbagai hasil studi menjukan bahwa pembangunan pariwisata berdampak baik terhadap perekonomian dan penciaptaan lapangan kerja. Sebagai case misanya penelitian dari (Chindris-Vasioiu \& Tocan, 2015) di Romania. Hasil penelitian tersebut menyimpulkan bahwa:

Besides allowing a higher valorization of naturalresources, tourism contributes to the development oflocal economies. Another important role that tourism has in national economies is to generate jobs and help decrease unemployment. The contribution of tourism in sociohuman sector is as important as in economic terms.

Dalam case yang berbeda, hasil penelitian (Bento, 2016) di Portugal, menyimpulkan bahwa "The results are indicative of a causal link amongst domestic tourists and economic growth, and therefore this study confirms that tourism is an important source of economic growth". Pada penelitian yang berbeda yang dilakukan oleh (Pratt, 2015), pada beberapa provinsi di China menyimpulkan bahwa "The tourism industry in China has increased dramatically in recent years. Because of larger multiplier effects, the more economically developed provincial economies will experience greater economic benefits as a result of further increases in tourism".

Merujuk pada berbagai hasil studi di atas maka dapat maknai bahwa secara industrial pariwisata merupakan salah satu sektor yang cukup berpengaruh dalam proses perkembangan dan pembangunan suatu wilayah. Oleh karena itu, Undangundang Nomor 10 Tahun 2009 tentang Kepariwisataan menjelaskan bahwa "pembangunan kepariwisataan diperlukan untuk mendorong pemerataan kesempatan berusaha dan memperoleh manfaat serta mampu menghadapi tantangan perubahan kehidupan lokal, nasional, dan global".

\section{METODE}

Penelitian ini menggunakan pendekatan deskriptif kualitatif, dan sumber data diperoleh dengan menggunakan instrumen manusia, peristiwa dan dokumen. Metode mendapatkan data adalah wawancara, observasi, dokumentasi. Teknik analisis data yang digunakan adalah model interaktif (Miles et al., 2015), dengan tahapan: kondensasi kata (data condensation), penyajian data (display data), dan kesimpulan/verivikasi (drawing/ verifiying). 


\section{HASIL DAN PEMBAHASAN}

\section{Pengembangan Potensi Pertanian Kampung Kalaodi Sebagai Objek Wisata Agro Kota Tidore Kepulauan}

Kampung Kalaodi telah dikonsepkan oleh pemerintah Kota Tidore Kepulauan sebagai objek wisata agro daerah. Bahkan dalam kebijakan pembangunan ekonomi daerah, pemerintah Kota Tidore Kepulauan menjadikan agrowisata Kalaodi sebagai objek wisata unggulan daerah. Hal tersebut disebut secara tegas dalam Pasal 20 Peraturan Daerah Nomor 9 Tahun 2015 tentang RIPPARDA Kota Tidore Kepulauan. Merujuk pada kebijakan daerah tersebut maka pemerintah Kota Tidore Kepulauan mempunyai kewajiban mengembangkan sektor pertanian di kampung Kalaodi, dan mendorong pengembangan sektor pertanian menjadi objek wisata agro sebagaimana yang diopsesikan. Riilnya adalah pemerintah harusnya memfasilitasi masyarakat Kalaodi untuk mengembangkan pertaniannya dalam bentuk program-program agrowisata sehingga wisatawan tertarik untuk mengunjungi kampung Kalaodi sebagai objek wisata agro daerah.

Dalam konteks pembangunan daerah, diperlukan kerjasama yang sinergis antara pemerintah daerah dan masyarakat. Dengan demikian maka dalam case ini, yaitu pengembangan pertanian di kampung Kalaodi sebagai objek agrowisata unggulan daerah harusnya disiapkan oleh pemerintah daerah bersama dengan masyarakat kampung Kalaodi. Namun demikian, pemerintah daerah melalui satuan perangkat daerah atau dinas terkait hadir sebagai leader dan sebagai motor penggeraknya. Agrowisata Kalaodi yang telah dijadikan kebijakan daerah, idealnya pemerintah daerah melalui SKPD terkait menterjemahkan dan mengoperasionalisasikan kebijakan daerah tersebut dalam bentuk program kerja sehingga harapan dari kebijakan daerah tersebut dapat diwujudkan.

Hasil studi menunjukan bahwa pengembangan program pada sektor kepariwisataan agro untuk mewujudkan kebijakan daerah, baik untuk agrowisata Kalaodi maupun di tempat lainnya belum dikonsepkan. Namun demikian, masyarakat yang ada di kampung Kalaodi telah menyadari bahwa kampung mereka telah ditetapkan dan dijadikan sebagai objek agrowisata, tidak hanya sebagai objek, tetapi menjadi objek wisata unggulan. Kesadaran tentang hal tersebut terlihat dengan upaya yang dilakukan oleh masyarakat, tokoh adat dan pemerintah kelurahan untuk mengembangkan hasil pertaninan dan perkebunan yang ada dikampung tersebut sebagai objek wisata. Program pemerintah kelurahan dan didukung oleh masyarakat untuk menjadikan kampungnya sebagai objek wisata agro dengan cara memanfaatkan pekarangan rumahnya untuk menanam berbagai jenis sayur-mayur.

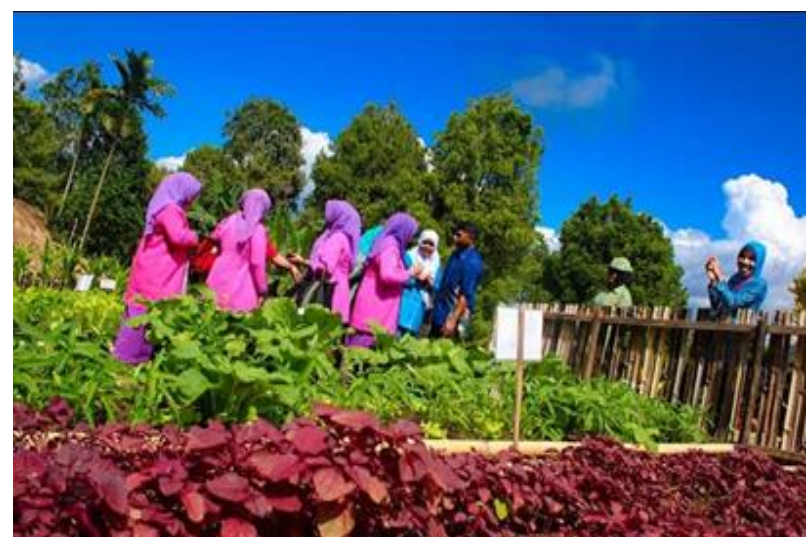

Gambar 1. Pemanfaatan Pekarang Sebagai Lahan Pertanian (Sumber: Kantor Kelurahan Kalaodi, 2017) 
Selain itu, masyarakat kampung Kalaodi yang keseharian berprofesi sebagai petani memanfaatkan lahan pertanian yang dimilikinya untuk menanam berbagai tanaman pertaninan. Hasil dari usaha pertanian tersebut telah membantu masyarakat secara ekonomi, karena melalui hasil panen pertanian tersebut dikonsumsi sendiri untuk memenuhi kebutuhan rumahtangganya, dan juga dijual ke para pengunjung yang berkunjung di kampung Kalaodi, serta dijual ke pasar Sarimalaha. Aktifitas keseharian masyarakat kampung Kalaodi sebagai petani dalam membuka lahan pertanian, menanam berbagai produk pertaninan, serta memanen dan memasarkannya, secara tidak langsung telah mengembangkan agrowisata di kampungannya.

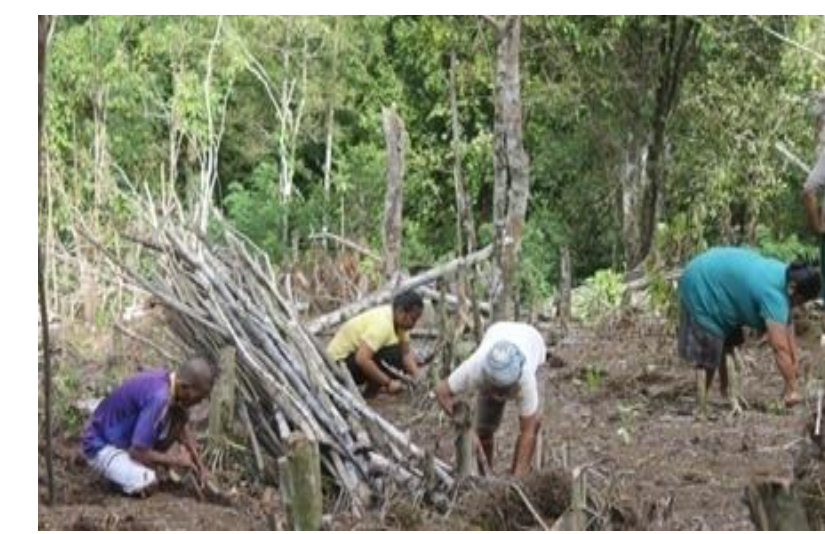

Gambar 2. Cara Bertani Masyarakat di Kampung Kalaodi (Sumber: Kantor Kelurahan Kalaodi, 2019)

Pada sisi yang lain, terdapat sebuah kesadaran kearifan lokal dalam aktifitas pertaninan dan perkebunan yang dipraktekan oleh masyarakat kampung Kalaodi dalam melaksanakan profesinnya adalah menjaga alam dan melindungi hutan. Praktek kearifan lokal masyarakat kampung Kalaodi tersebut merupakan sebuah paraktek yang sangat langka. Praktek pertaninan dan perkebunan yang dilakukan oleh masyarakat kampung Kalaodi tersebut secara tidak lansung telah melakukan pengembangan agrowisata di kampungnya. Jika kesadaran dan upaya yang telah dilakukan oleh masyarakat kampung Kalaodi tersebut didukung oleh pemerintah Kota Tidore Kepulauan, melalui instansi daerah terkait seperti Dinas Pertanian dan Perkebunan, maka sektor pertaninan yang ada di kampung Kalaodi dapat berkembang lebih baik lagi. Dengan berkembangnya sektor pertanian dan perkebunan di kampung Kalaodi maka secara tidak langsung mendorong perkembangan agrowisata di kampung tersebut. Manfaat lain yang dapat dinikmati oleh masyarakat dengan berkembangnya sektor pertaninan dan agrowisata adalah bertumbuhnya perekonomian masyarakat.

Dalam berbagai hasil penelitian menunjukan bawa agrowisata memberikan kontribusi yang positif bagi daerah dan masyarakat. Dengan demikian maka, daerah tujuan wisata yang memiliki objek wisata agro harus mengembakan potensi wisata agronya dan pengembangan agrowisata dapat memberdayaan dan meningkatkan pendapatan masyarakat desa (Budiarti et al., 2013).

Dalam perkembangan terakhir, tren pengembangan pertanian menjadi sumberdaya dan daya tarik wisata dikerenakan semakin banyak wisatawan berkeinginan untuk dekat dengan lingkungan alam. Adanya tren tersebut merupakan sesuatu yang wajar dikarenakan hampir setiap saat, utamanya masyarakat perkotaan hidup di dalam ruang-ruang beton dan kaca. Para wisatawan cenderung untuk melakukan berbagai perjalanan wisata ke lokasi yang relatif sepi dan alami, memiliki udara yang bersih dan segar serta mempunyai atraksi yang menarik dan unik. Secara 
empiris, karakterisik tersebut pada umumnya terdapat pada kawasan perkampungan pedesaan. Artinya, pilihan berwisata masyarakat saat ini cenderung ke aderah pedesaan yang masih alami alamnya dengan perkampungan dengan karakter pedesaan.

Membaca fenomena tersebut maka daerah perkampungan yang memiliki karakter alam dengan hutan yang lebat dan rindang serta udara yang masih segar dan sejuk dapat mengembangkan kampungnya menjadi objek wisata, dengan tajuk agrowisata. Departemen Pertanian (Utama, 2015) menjelaskan agrowisata merupakan salah satu kegiatan pada bidang pertaninan dengan cara menjual jasa pelayanan. Bentuk jasa yang dijual berupa keindahan alam, kenyamanan ketenraman, dan pendidikan. Pada sisi yang lain kedatangan dan kegiatan wisatawan di daerah agrowisata akan berdampak pada aktivitas usaha masyarakat setempat. Secara tidak langsung dapat menciptakan lapangan pekerjaan, mendiversifikasi kegiatan ekonomi masyarakat pedesaan. Dampak penting lain dari kegiatan tersebut adalah memberikan manfaat ekonomi maupun sosial budaya bagi masyarakat tersebut. Pengembangan agrowisata juga meningkatkan kapasitas masyarakat dalam pengorganisasian masyarakat yang berperan dalam kegiatan pembangunan desa wisata (Prafitri \& Damayanti, 2016).

Selian itu, secara umum merujuk pada berbagai hasil studi menjukan bahwa pembangunan pariwisata berdampak baik terhadap perekonomian dan penciaptaan lapangan kerja. Sebagai case misanya penelitian dari Chindris-Vasioiu dan Tocan (2015) di Romania, penelitian oleh Bento (2016) di Portugal, dan juga penelitian oleh Pratt (2015), di China, yang secara umum menyimpulkan bahwa pembangunan kepariwisataan dapat menciptakan lapangan kerja, dan membangkitkan berbagai sektor industri. Manfaat dari pengembangan pariwisata adalah dapat menumbuhkan perekonomian masyarakat, daerah dan negara.

Merujuk pada berbagai konsep dan hasil studi tersebut, maka kampung Kalaodi dengan keseharian masyarakatnya yang berprofesi sebagai petani dapat mengembangkan kampung sebagai objek wisata agro. Pengembangan pertanian masyarakat kampung Kalaodi sebagai objek agrowisata, secara konseptual dapat meningkatkan pendapatan dan kesejarhetraan masyarakat. Pada sisi yang lain, secara tidak langsung dapat mengerakan dan meningkatkan perekonomian daerah. Namun demikian, berdasarkan data yang tersaji di depan menunjukan bahwa upaya pengembangan agrowisata yang telah dilakukan oleh masyarakat kampung Kalaodi belum mendapat sentuhan dari program pemerintah daerah.

\section{Pengembangan Industri Rumahan (Home Idustry) Sebagai Upaya Peningkatan Ekonomi Masyarakat}

Salah satu upaya yang dapat dilakukan dalam pengembangan pariwisata, utama agrowisata adalah mengembangkan industri rumahan (home idustry). Dalam pengembangan agrowisata, keberadaan home industry mempunyai peran yang sangat penting. Melalui home industry, masyarakat setempat dapat mengolah hasil pertanian atau perkebunannya menjadi suatu produk, berupa makanan, panganan, dan kerajinan tangan. Hasil produksi home industry tersebut yang nantinya dijual oleh masyarakat ke pengungunjung atau wisatawan yang berkunjung ke kampungnya. 


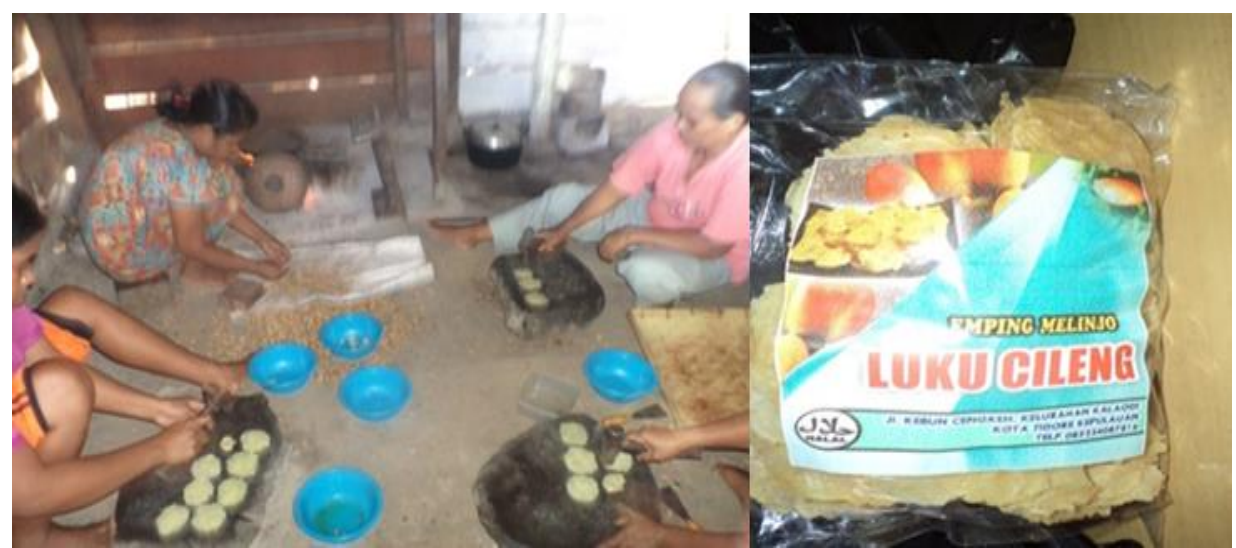

Gambar 3. Proses Pembuatan Emping dan Kripik Malinjo Produk Industri Rumahan Kampung Kalaodi (Sumber: Kantor Kelurahan Kalaodi, 2019)

Pada case agrowisata kampung Kalaodi, berdasarkan data Dinas Perindustrian, Perdagangan, Komprasi dan UKM, pada wilayah administrasi Kelurahan Kalaodi yang menjadi wialayah pengembangan agrowisata Kalaodi, belum terdapat unit usaha indusri yang terdaftar di Dinas tersebut. Namun, di kampung Kalaodi terdapat kegiatan home industry yang dilakukan dan dikembangkan oleh masyarakat. Namun demikian, secara empirik terdapat aktifitas home industry yang dijalankan dan dikembangkan oleh masyarakat (Tini, 2019). Home industry yang digerakan oleh masyarakat adalah mengolah hasil perkebunan sendiri yaitu buah melinjo menjadi emping dan krepek malinjo. Melalui kreatifitas masyarakat, produk emping malinjo telah memiliki farian rasa selai rasa orisinilnya, yaitu rasa manis dan pedas.

Selain home industry yang mengasilkan produk penganan berupa emping dan krepek malinjo, terdapat juga industri rumahan yang bergerak dibidang keterampilan yang menghasilkan produk berupa sovenir dan perhiasan serta perabot rumah tangga. Dalam amatan penulis, di kampung Kalaodi terdapat beberapa aktifitas masyarakat yang dapat dikategorikan sebagai industri rumahan, yang walaupun belum memiliki legalitas dari pemerintah. Diantara aktifitas masyarakat tersebut yang bergerkaitan dengan ketrampilan tangan yang menghasilkan berbagai produk seperti hiasan rumah, perabot rumah tangga, dan peralatan pertaninan yang dibutuhkan oleh para petani. Selain itu, terdapat juga produk gantungan kunci yang dibuat oleh masyarakat dengan icon peralatan budaya khas Kalaodi.

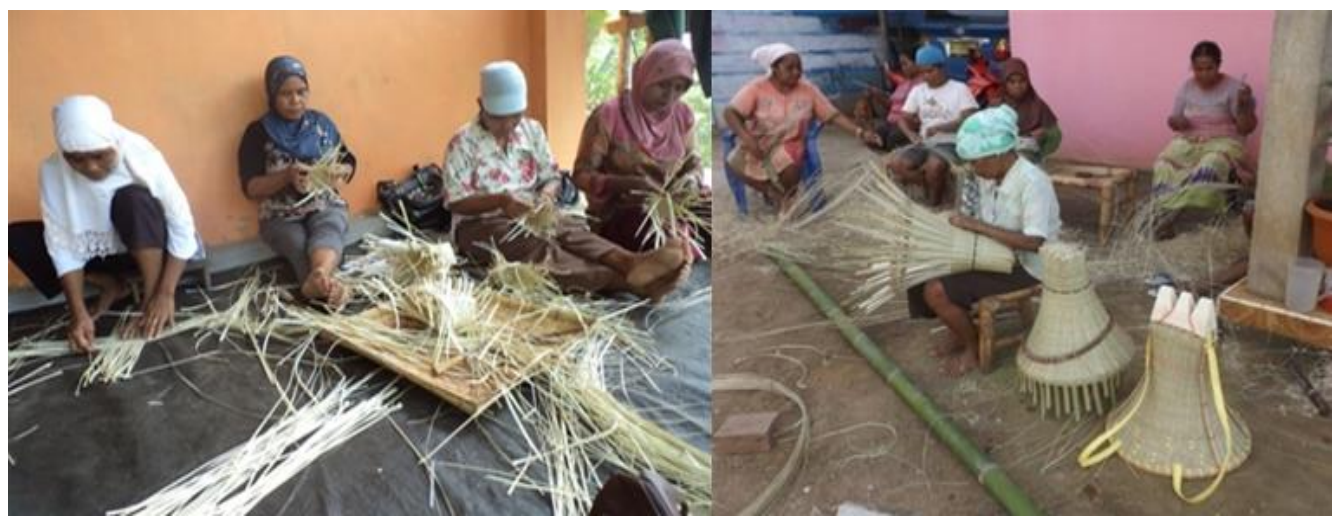

Gambar 4. Aktifitas Masyarakat Pembuatan Anyaman Sovenir dan Prabot Rumatangga di Kampung Kalaodi

(Sumber: Kantor Kelurahan Kalaodi, 2019) 
Harapannya dengan adanya home industry tersebut dapat meningkatkan perekonomian masyarakat. Pada beberapa case menunjukan bahwa pengembangan usaha masyarakat dalam konteks pembangunan kepariwisataan dapat emningkatkan perekonomian masyarakat. Hal tersebut sebagai hasil penelitian yang dilakukan oleh Sriyadi di Desa Kebon Agung Kecamatan Imogiri Kabupaten Bantul sebagai berikut:

"Pengembangan agrowisata mendorong masyarakat melakukan pengolahan hasilhasil pertanian, meningkatkan pengelolaan usahatani dan pengelolaan di luar usahatani, dan dari hasil pengolahan hasil-hasil pertanian, pengelolaan usahatani dan pengelolaan kegiatan di luar usahatani dapat meningkatkan pendapatan rumah tangga petani yang cukup signifikan. Untuk mengoptimalkan pengolahan hasil-hasil pertanian, pengelolaan usahatani dan pengelolaan kegiatan di luar usahatani" (Sriyadi \& Francy Risvansuna F, 2015).

Merujuk hasil studi di atas maka dapat dijelaskan bahwa pengembangan agrowisata dengan pendekatan pengembangan industri rumahan yang dikembangkan oleh masyarakat yang mengelola hasil pertanian dan perkebunan mempunyai nilai strategis. Pada sisi yang lain, dengan usaha rumahan yang dilakukan oleh masyarakat tersebut meningkatkan kreatifitas usaha masyarakat dalam mengolela hasil produk pertaniannya. Masyarakat juga dapat meningkatkan nilai jual dari produk pertanian dan perkebunannya, karena tidak menjualnya secara langsung pasca panen tetapi, menjual produk dalam bentuk panganan atau makanan yang berbahan baku hasil pertanian mereka. Nilai penting lain yang dapat didapatkan dari masyarakat adalah peningkatan perekonomian masyarakat.

Melalui case hasil studi di atas, maka dapat dijadikan sebagai sumber inspirasi untuk masyarakat kampung Kalaodi dalam pengembangan home industry sebagai suatu upaya untuk pengembangan agrowisata Kalaodi. Selain sebagai upaya pengembangan agrowisata, home industry yang dikembangkan masyarakat dapat meningkatkan pendapatan masyarakat kampung Kalaodi. Berdasarkan hasil menunjukan bahwa masyarakat kampung Kalaodi mendapatkan nilai ekonomi dari usaha yang dikembangkannya. Melalui usaha home industry tersebut dapat membantu meringankan beban ekonomi keluarga. Pada sisi yang lain, masyarakat berharap pemerintah dapat membantu usaha yang digerakan oleh mereka, sehingga produksinya dapat ditingkatkan, yang nantinya dapat meningkatkan pendapatan usaha dari usaha yang dikelolanya. Dengan adanya peningkatan produksi dan pendapatan tersebut, maka akan dapat meningkatkan pendapatan para pengelolanya, yang akhirnya dapat meningkatkan perekonomian masyarakat.

Diantara tujuan dari pengembangan usaha rumah tangga adalah untuk meningkatkan nilai produk dari hasil pertanian dan perkebunan yang sesunggunya merupakan pemanfaatan sumberdaya kekayaan alam yang dimiliki oleh negara ini. Pada sisi yang lain, dengan hadirnya home industry tersebut menciptakan lapangan kerja dan secara tidak langsung telah membantu pemerintah dalam hal mengurangi angka pengangguran.

Dalam kontek pembangunan ekonomi, idealnya usaha rumahan yang secara konseptual masuk dalam kategori usahakecil merupakan kegiatan yang sangat yang harus mendapatkan perhatian lebih dari pemerintah, karena potensinya yang besar dalam menggerakan potensi ekonomi masyarakat. Selain itu, industri rumahan sekaligus menjadi tumpuan pendapatan sebagaian besar masyarakat dalam memenuhi 
kebutuhan hidupnya. Data statestik menunjukan bahwa usaha kecil dari tahun ke tahun meningkatkan penyerapan tenaga kerja, pertumbuhan investasi.

Realitas tersebut menjelaskan bahwa usaha kecil dan menengah dalam hal ini usaha industri rumah tangga merupakan kegiatan usaha yang mampu memperluas lapangan kerja memberikan pelayanan ekonomi secara luas kepada masyarakat, dan dapat berperan dalam proses pemerataan dan peningkatan pendapatan masyarakat, mendorong pertumbuhan ekonomi, dan berperan dalam mewujudkan stabilitas nasional. Namun demikian permasalahan yang dihadapi banyak usaha kecil menengah saat ini adalah keterbatasan kualitas sumber daya manusia selaku pelaku usaha kecil menengah ditandai dengan masih minim pendidikan yang dimiliki, serta akses terhadap sumberdaya produktif seperti keterbatasan permodalan. Oleh karena itu, maka yang perlu dilakukan adalah upaya strategi pemberdayaan usaha kecil menengah melalui pengembangan sumber daya manusia dengan cara melakukan pelatihan. Sedangkan untuk mengatasi masalah permodala adalah dengan cara peningkatan akses usaha kecil menengah terhadap perluasan penyaluran kredit usaha rakyat serta peningkatan produktivitas melalui kemitraan.

Merujuk pada pembahasan di atas maka dapat dijelaskan bahwa masyarakat kampung Kalaodi yang telah menggerakan usaha rumahan dapat mengembangkan usaha dalam upaya peningkatan ekonomi rumah tangga. Dengan adanya usaha masyarakat tersebut secara tidak langsung dapat menggerakan pereonomian daerah dan meningkatkan pendapatan masyarakat. Namun demikian, diperlukan perhatian dari pemerintah dalam bentuk kebijakan dan program yang berpihak kepada masyarakat.

Kampung Kalaodi yang telah ditetapkan oleh pemerintah daerah sebagai salah satu objek wisata agro, dengan berbagai kekayaan agronya dapat mengembangkan perkampungannya sebagai salah satu destinasi pariwisata di Kota Tidore Kepulauan. Pengemabangan pengembangan kampung Kalaodi sebagai objek wisata, utamanya wisata agro diperlukan dukungan program dari pemerintah. Masyarakat kampung Kalaodi tidak bisa dibiarkan berjalan sendiri dalam mewujudkan kebijakan pemerintah tentang agrowisata Kalaodi. Diantara program yang harus dilakukan oleh pemerintah, utamanya pemerintah daerah adalah pemeberdayaan masyarakat, seperti pengembangan sumberdaya manusia yang berkaitan dengan kepariwisataan, pemberdayaan ekonomi kreatif yang berbasis pada lingkungan ekonomi masyarakat, perlindungan dan pengembangan budaya yang berbasisi pada kearifan masyarakat.

\section{KESIMPULAN}

Agrowisata Kalaodi yang telah menjadi kebijakan daerah, harusnya dikembangkan dalam bentuk program dan kegiatan daerah secara riil. Pemerintah daerah melalui dinas terkait, utamanya Dinas Kebudayaan dan Pariwisata bersama stakeholders pariwisata lainnya harus bersama-sama mengkonsepkan pogram pengembangan agrowisata daerah. Pada sisi yang, sektor swasta dan masyarakat daerah harus difasilitasi dan diberdayakan oleh pemerintah daerah untuk terlibat secara langsung dalam pembangunan pariwisata daerah, khususnya agrowisata Kalaodi. Berdasarkan hasil studi menunjukan bahwa, Dinas Kebudayaan dan Pariwisata, serta instansi terkait lainnya belum mempunyai program dan kegiatan pengembangan pariwisata daerah secara umum, maupun agrowisata Kalaodi secara khusus.

Namun demikian, masyarakat Kalaodi berinisiatif mengembangkan potensi agrowisata yang dimilikinya. Usaha yang dilakukan oleh masyarakat adalah memanfaatkan pekarangan rumah sebagai kebun keluarga yang hasilnya dinikmati oleh masyarakat. 
Selain itu, masyarakat Kalaodi memiliki kearifan lokal dalam menjalankan profesinya sebagai petani, yaitu bertani yang tidak merusak hutan dan alam. Kearifan tersebut memperkaya agro wisata kampung Kalaodi.

Pada ruang yang berbeda, dalam upaya mengembangkan kampungnya sebagai kampung agrowisata, masyarakat Kalaodi mengembangkan berbagai home industry. Diantara produk dari industri rumahan tersebut adalah krepek dan emping malinjo, sovenir serta perhiasan dan perabot rumah tangga. Secara ekonomi, usaha home industry yang dikembangkan oleh masyarakat tersebut mempunyai dampak terhadap masyarakat seperti membantu ekonomi keluarga.

\section{DAFTAR RUJUKAN}

Bento, J. P. C. (2016). Tourism and economic growth in Portugal: an empirical investigation of causal links. Tourism \& Management Studies, 12(1), 164-171. https://doi.org/10.18089/tms.2016.12117

Budiarti, T., Suwarto, \& Muflikhati, I. (2013). Pengembangan Agrowisata Berbasis Masyarakat Pada Usahatani Terpadu Guna Meningkatkan Kesejahteraan Petani Dan Keberlanjutan Sistem Pertanian. Jurnal Ilmu Pertanian Indonesia, 18(3), 200-207.

Camilleri, M. A. (2018). The Tourism Industry: An Overview. In In Travel Marketing, Tourism Economics and the Airline Product. https://doi.org/10.1007/978-3-31949849-2_1

Chindris-Vasioiu, O., \& Tocan, M. (2015). Sustainable Development in Tourism - Factor of Economic Growth. Knowledge Horizons - Economics, 7(2), 160-164. https://doi.org/https://EconPapers.repec.org/RePEc:khe:journl:v:7:y:2015:i:2:p:16 $0-164$

Miles, M. B., Huberman, A. M., \& Saldaña., J. (2015). Qualitative Data Analysis: A Methods Sourcebook and The Coding Manual for Qualitative Researchers. Journal Technical Communication Quarterly, https://doi.org/10.1080/10572252.2015.975966

24(1),

381.

Pambudi, S. H., Sunarto, N., \& Setyono, P. (2018). Strategi Pengembangan Agrowisata dalam Mendukung Pembangunan Pertanian - Studi Kasus di Desa Wisata Kaligono (Dewi Kano) Kecamatan Kaligesing Kabupaten Purworejo. Analisis Kebijakan Pertanian, 16(2), 159-177. https://doi.org/10.21082/akp.v16n2.2018.165-184

Permana, Y. S. (2010). Kontestasi Abangan-Santri Pasca Orde Baru di Pedesaan Jawa. Jurnal Ilmu Sosial Dan Ilmu Politik, 14(1), 63-82. https://doi.org/10.22146/jsp.10949

Prafitri, G. R., \& Damayanti, M. (2016). Kapasitas Kelembagaan Dalam Pengembangan Desa Wisata (Studi Kasus: Desa Wisata Ketenger, Banyumas). Jurnal Pengembangan Kota, 4(1), 76. https://doi.org/10.14710/jpk.4.1.76-86

Pratt, S. (2015). Potential Economic Contribution of Regional Tourism Development in China: A Comparative Analysis. International Journal of Tourism Research, 17(3), 303-312. https://doi.org/10.1002/jtr.1990

Rambodagedara, R. M. M. H. K., Silva, D. A. C. S., \& Perera, S. (2015). Agro-Tourism Development in Farming Community: Opportunities and Challenges (D. Hewavitharana (ed.); Issue October). Hector Kobbekaduwa Agrarian Research and Training Institute. https://doi.org/accessed 16/12/2018

Rivai, R. S., \& Anugrah, I. S. (2011). Konsep dan Implementasi Pembangunan Pertanian Berkelanjutan di Indonesia. Forum Penelitian Agro Ekonomi, 29(1), 13-25. https://doi.org/10.21082/fae.v29n1.2011.13-25

Rosana, M. (2018). Kebijakan Pembangunan Berkelanjutan Yang Berwawasan Lingkungan di Indonesia. Jurnal KELOLA: Jurnal Ilmu Sosial, 1(1), 148-163. 
https://doi.org/10.15575/jk.v1i1.4128

Situmorang, M., \& Suryawan, I. B. (2017). Tinjauan Potensi Agrowisata Di Kawasan Bedugul. Jurnal Destinasi Pariwisata, 5(1), 160-169. https://doi.org/10.24843/jdepar.2017.v05.i01.p29

Sriyadi, \& Francy Risvansuna F. (2015). Model Pengembanganagrowisata Berbasis Kearifan Lokal (Studi Kasus di Desa Kebon Agung Kecamatan Imogiri Kabupaten Bantul Daerah Istimewa Yogyakarta) (Vol. 16, Issue 2). Universitas Muhammadiyah Yogyakarta.

Sudalmi, E. S. (2010). Pembangunan pertanian berkelanjutan. INNOFARM : Jurnal Inovasi Pertanian, $9(2)$,

15-28.

http://ejurnal.unisri.ac.id/index.php/innofarm/article/view/28

Suwena, I. K., \& Widyatmaja, I. G. N. (2017). Pengatahuan Ilmu Dasar Pariwisata (Edisi Revi, p. 240). Pustaka Larasan.

Syafira, R. (2017). Strategi Pengembangan Inti Agrowisata Dengan Pendekatan Business Model Canvas. Institut Pertanian Bogor.

Tini, D. L. R. (2019). Pengembangan Program Usaha Ekonomis Produktif dalam Pemberdayaan Perempuan di Kabupaten Sumenep. Jurnal Inovasi Ilmu Sosial Dan Politik (JISoP), 1(2), 148. https://doi.org/10.33474/jisop.v1i2.4801

Yunas, N. S. (2018). Desain Kebijakan Reformasi Sistem Perpajakan Melalui e-Taxation di Indonesia: Belajar Pada Keberhasilan Reformasi Sistem Perpajakan di Jepang. CosmoGov: Jurnal Ilmu Pemerintahan, 4(1), 71-89. https://doi.org/10.24198/cosmogov.v4i1.14214 